\title{
REVIEW
}

\section{Mechanisms of action underlying the immunotherapeutic activity of Allovectin in advanced melanoma}

\author{
J Doukas and A Rolland
}

\begin{abstract}
Allovectin (velimogene aliplasmid) is a cancer immunotherapeutic currently completing a pivotal phase 3 study for metastatic melanoma. Consisting of a bicistronic plasmid encoding both major histocompatibility complex (MHC) class I heavy and light chains (HLA-B7 and $\beta 2$-microglobulin, respectively) formulated with a cationic lipid-based system, it is designed for direct intratumoral administration. Following injection into a single lesion, the product is intended to induce anti-tumor immune responses against both treated and distal lesions. Both the plasmid and lipid components of Allovectin contribute to the biological activity of the drug product, and its therapeutic activity is hypothesized to derive from multiple mechanisms of actions (MOAs). These include the induction of both cytotoxic T-cell and innate immune responses directed against allogeneic as well as tumor-derived targets, consequences of both an increased MHC class I expression on tumor cells and the induction of a localized immune/inflammatory response. In this paper, we review Allovectin's proposed MOAs, placing their contributions in the context of anti-tumor immunity and highlighting both preclinical and clinical supporting data.
\end{abstract}

Cancer Gene Therapy (2012) 19, 811-817; doi:10.1038/cgt.2012.69; published online 5 October 2012

Keywords: immunotherapy; lipid; melanoma; MHC class I; plasmid; T cell

\section{INTRODUCTION}

Melanoma accounts for a minority of skin cancer diagnoses but at the same time results in the great majority of skin cancer deaths. Incidence trends have steadily increased for the last several decades to a 2012 estimate of over 76000 diagnoses and 9000 deaths in the United States alone. ${ }^{1}$ Encouragingly, two new therapeutic options were recently approved based on survival benefits, the small molecule vemurafenib (Zelboraf), which targets the BRAF ${ }^{\mathrm{V} 600 \mathrm{E}}$ mutation, ${ }^{2}$ and the monoclonal antibody ipilimumab (Yervoy), which binds to and blocks CTLA-4 (CD152). ${ }^{3}$ Unfortunately, these new therapies are also associated with an increased risk of adverse events, and further investigation is needed to identify additional therapies as well as combinational approaches. It is encouraging then that the momentum towards new treatment options continues with other therapeutics in advanced clinical trials, among these velimogene aliplasmid (Allovectin). ${ }^{4}$

Allovectin is an investigational plasmid DNA (pDNA)-based immunotherapy administered into a single tumor lesion. It consists of a plasmid (VCL-1005) formulated with a cationic lipid-based system. VCL-1005 is a bicistronic pDNA encoding two transgene proteins, a major histocompatibility complex (MHC) class I heavy chain (HLA-B7) and the light chain common to class I molecules, $\beta 2$-microglobulin $(\beta 2 \mathrm{M})$. A mixture of a cationic lipid (dimyristyloxypropyl-3-dimethyl-hydroxyethyl ammonium; DMRIE) and a neutral lipid (dioleoyl phosphatidylethanolamine; DOPE) is formulated with VCL-1005 to yield the drug product, a pDNA/lipid complex suspension.

A review of Allovectin's clinical development history was recently published. ${ }^{5}$ Highlights include a phase 2 study in advanced metastatic melanoma patients (stages III and IVa/IVb) that showed a good safety profile, an $11.8 \%$ response rate and a median overall survival of 18.8 months; $^{6}$ a phase 3 trial in chemonaive, recurrent metastatic melanoma patients completed enrollment and as of this writing is in the patient follow-up stage. ${ }^{5}$ In this paper, we review the possible biological activities that underlie Allovectin's anti-tumor activity, using preclinical study data to illustrate key points.

\section{PROPOSED MECHANISMS OF ACTION (MOAS)}

Allovectin is designed to stimulate both innate and adaptive immune responses and as a result to induce both loco-regional and systemic anti-tumor effects. Three MOAs are believed to underlie this immunotherapeutic activity: the induction of cytotoxic T-cell (CTL) responses directed against an allogeneic target (HLA-B7) introduced on tumor cells, the induction of CTL responses directed against tumor antigens (following restoration of MHC class I expression), and the induction of innate immune/ inflammatory responses. These responses can be divided into two broad groups: transgene-related and pDNA/lipid-related.

\section{Transgene contributions}

The original concept behind Allovectin's design was to introduce an allogeneic target onto tumor cells, a concept that originated in murine studies, demonstrating that the expression of allogeneic $\mathrm{MHC}$ on tumor cells rendered these cells susceptible to immunemediated destruction. 7 The intratumoral administration of Allovectin is intended to facilitate VCL-1005 access to and uptake by cancer cells; the resulting expression of the plasmid's two transgenes by cancer cells should result in presentation of HLA-B7/ $\beta 2 \mathrm{M}$ complexes on the surface of these cells. HLA-B7 complexes expressed on tumor cells in HLA-B7-negative patients would then be recognized as a foreign allele, allowing for a

Vical Incorporated, San Diego, CA, USA. Correspondence: Dr J Doukas, Senior Director Preclinical Safety and Efficacy, Vical Incorporated, 10390 Pacific Center Court, San Diego, CA 92121-4340, USA. 
T-cell-based allogeneic response directed against the tumor. According to an online database of gene frequencies, ${ }^{8} \sim 85 \%$ of the human population is negative for HLA-B7 alleles and therefore could be susceptible to this mechanism of action.

VCL-1005 should lead to efficient expression of HLA-B7 on the cell surface as both the heavy and light chain of a complete HLA class I molecule are provided. Increased expression of $\beta 2 \mathrm{M}$ in transfected cancer cells, however, could also have additional effects. By combining with MHC class I heavy chains present endogenously within the cell, $\beta 2 \mathrm{M}$ could enhance the expression of multiple class I alleles on the cell surface, alleles beyond simply HLA-B7. MHC class I molecules assemble intracellularly as heavy and light chains combine, and following correct folding and peptide loading they are exported to the cell surface. ${ }^{9}$ In the absence of $\beta 2 \mathrm{M}$, most heavy chain molecules remain within the cytoplasmic compartment and eventually degrade; ${ }^{10}$ transfection with VCL-1005 could rescue these heavy chains and allow for their export as peptide-loaded HLA complexes.

Restoration of tumor cell MHC class I expression is very desirable as class I down-regulation is a common mechanism by which tumors evade immune surveillance. ${ }^{11}$ Reduced expression of MHC class I, and in particular HLA-B, has been long been recognized in human melanomas, ${ }^{12-15}$ and as CTL activity directly correlates with the level of class I surface expression, this results in poor anti-tumor immune responses. ${ }^{16}$ Restoration of MHC class I expression might therefore correct the inability of $\mathrm{CD}^{+}{ }^{+} \mathrm{T}$ cells to recognize tumor cells, as class I expression on melanoma biopsies has been positively correlated with T-cell infiltration, ${ }^{17}$ with both thinner lesions and a more favorable disease stage, ${ }^{13,18}$ and with slower time to disease progression and longer survival. ${ }^{18,19}$

Enhancing $\beta 2 \mathrm{M}$ expression in tumor cells should be a particularly efficient means of restoring MHC class I expression, as $\beta 2 \mathrm{M}$ defects appear to underlie much of the class I deficiency in melanoma. For example, deletions and mutations have been observed in several melanoma-derived cell lines resulting in the loss of $\beta 2 \mathrm{M}$ translation, while transfection with a wild-type $\beta 2 \mathrm{M}$ restores MHC class I expression to these cells. ${ }^{20-23}$ Loss of $\beta 2 \mathrm{M}$ also appears to underlie the immune resistance that develops in some melanomas following immunotherapy. ${ }^{22,24}$

Restoration of MHC class I expression on tumor cells, be it HLAB7 or endogenous alleles, would then allow for the presentation of tumor antigens to CTL. While it has long been recognized that tumor cells can express unique antigens that represent potential T-cell targets, ${ }^{25,26}$ it is believed that inherently low antigenicity on the part of the antigen and/or poor MHC presentation on the part of the cell limits their impact on anti-tumor immune responses. Immunotherapeutic approaches based on the transfer of tumorinfiltrating lymphocytes, or more recently on $T$ cells transfected with chimeric antigen receptors, aim to improve the anti-tumor antigen CTL response to a degree where clinical benefit is achieved. ${ }^{27}$ Allovectin immunotherapy seeks the same goal, in this case not by manipulating the responder cell population but rather the target cell population.

\section{Plasmid backbone and lipid contributions}

The rationale for using a cationic lipid-based formulation in Allovectin originated in the well-established literature demonstrating the benefits of such systems for pDNA delivery. These benefits can include DNA protection from nuclease degradation and plasmid condensation into structural units appropriate for cellular internalization and processing. ${ }^{28}$ The lipids used in Allovectin (DMRIE and DOPE) differ from those used in the first clinical trial to deliver HLA-B7 genes to tumors ${ }^{29}$ and were selected based on their improved ability to deliver pDNA to cells as well as their superior stability. ${ }^{30}$

Allovectin's lipid-based formulation, however, may provide other benefits in addition to pDNA delivery. Cationic lipid/pDNA complexes are very efficient at enhancing innate immune responses. ${ }^{31}$ They stimulate the production of Th1-like cytokine profiles from macrophages, dendritic cells and natural killer (NK) cells $^{31-34}$ and can induce anti-tumor activity with long-term systemic protection, responses not seen when either pDNA or lipid are administered alone. ${ }^{31,34-36}$ The MOA appears to encompass both innate and adaptive immune responses, as both NK cells and $\mathrm{CD}^{+}{ }^{+} \mathrm{T}$ cells are involved.

Some of the immune activating ability of cationic lipid/pDNA complexes may come from the pDNA. Plasmids are produced by a bacterial fermentation process and therefore, like bacterial DNA, contain unmethylated CpG sequences (cystosine-guanine dinucleotides separated by a phosphate group), which are relatively rare in mammalian cell DNA. When situated in an appropriate sequence motif unmethylated $\mathrm{CpG}$ form an immunostimulatory sequence recognizable by Toll-like receptor $9,37,38$ and upon binding to Toll-like receptor 9 on dendritic cells trigger the production of proinflammatory cytokines and a general activation of the innate immune response. ${ }^{39}$ However, it is clear that not all the proinflammatory response induced by cationic lipid/pDNA complexes is due to CpG motifs, as these complexes are meaningfully more active than either the lipid or pDNA components alone, ${ }^{31}$ as even mammalian DNA can stimulate murine macrophages to secrete tumor necrosis factor- $\alpha$ when delivered as cationic lipid complexes, ${ }^{32}$ and as these effects are not entirely dependent on Toll-like receptor $9 .^{40}$

Taken together, the pDNA structural motifs and cationic lipid complexes present in Allovectin are expected to create a proinflammatory environment that favors cellular recruitment and activation, and as a consequence tumor destruction. A further connection can also be made to Allovectin's transgene-mediated MOAs. Cationic lipid/pDNA complexes (but not pDNA or lipid alone) directly enhance endogenous MHC class I expression. ${ }^{41}$ This is likely a result of the cationic lipid-induced cytokine production previously described. Interestingly, MHC class I down-regulation in melanoma cells can be driven in part by the down-regulation of components of the antigen processing machinery and in many cases this can be overcome by cytokine (for example, IFN- $\gamma$ ) stimulation. ${ }^{15,42}$ The proinflammatory environment created by Allovectin could encompass increased cytokine stimulation of tumor cells and thus an additional means of increasing endogenous MHC class I expression on tumor cells, independent of but complementary to the delivery of HLA-B7 and $\beta 2 \mathrm{M}$ genes.

\section{PRECLINICAL DATA EXAMPLES}

\section{Plasmid optimization}

The first clinical tests of plasmid-directed HLA-B7 expression as a cancer immunotherapy used a plasmid that encoded only the heavy chain of the MHC molecule. ${ }^{29}$ While encouraging results were obtained, including demonstrations of HLA-B7 expression and immune responses directed against HLA-B7 as well as autologous melanoma cells, addition of a plasmid-directed $\beta 2 \mathrm{M}$ expression was considered as a means of improving $\mathrm{MHC}$ expression levels.

The advantage of HLA-B7 and $\beta 2 \mathrm{M}$ co-expression can be demonstrated in vitro by transfecting cells with either VCL-1004 (a monocistronic plasmid encoding only HLA-B7) or VCL-1005 (the bicistronic plasmid component of Allovectin encoding both HLA$B 7$ and $\beta 2 \mathrm{M})$. Transfection of a cell line deficient in endogenous $\beta 2 \mathrm{M}$ expression (such as the murine cell line VM92) with VCL-1004 leads to a relatively low-level expression of HLA-B7 on a minority (13\%) of cells (Table 1), whereas VCL-1005 yields not only a greater number of positive cells (60\%) but also a fourfold higher level of cell surface HLA-B7. When a cell line expressing $\beta 2 \mathrm{M}$ (such as the human cell line 293) is used, VCL-1004 is very efficient at increasing the number of HLA-B7 expressing cells, as would 
Table 1. Influence of $\beta 2$-microglobulin on HLA-B7 expression

\begin{tabular}{lcccccc}
\hline Treatment & \multicolumn{2}{c}{ VM92 cells } & & \multicolumn{2}{c}{293 Cells } \\
\cline { 2 - 3 } \cline { 5 - 6 } & $\begin{array}{c}\text { \% HLA-B7 } \\
\text { positive }\end{array}$ & $\begin{array}{c}\text { Mean } \\
\text { FI }\end{array}$ & & $\begin{array}{c}\text { \% HLA-B7 } \\
\text { positive }\end{array}$ & $\begin{array}{c}\text { Mean } \\
\text { FI }\end{array}$ \\
\cline { 3 - 4 } None & $3 \%$ & 39 & & $63 \%$ & 24 \\
VCL-1004 & $13 \%$ & 31 & & $93 \%$ & 58 \\
VCL-1005 & $60 \%$ & 123 & & $98 \%$ & 143 \\
\hline
\end{tabular}

VM92 cells (murine origin, HLA-B7 negative and $\beta 2 \mathrm{M}$ defective) or 293 cells (human origin, HLA-B7 and $\beta 2 \mathrm{M}$ positive) were transfected in vitro with either VCL-1004 (encoding HLA-B7) or VCL-1005 (encoding both HLA-B7 and $\beta 2 \mathrm{M}$ ), delivered as $5 \mu \mathrm{g}$ plasmid formulated with dimyristyloxypropyl-3-dimethyl-hydroxyethyl ammonium/dioleoyl phosphatidylethanolamine; cells that received no treatment were used as a control. Flow cytometry was then performed $48 \mathrm{~h}$ later to determine the percentage of cells expressing HLA-B7 (as detected by the monoclonal antibody BB7.1) and the mean fluorescence intensity (FI, in arbitrary units) of those cells.

be expected, for example in this study from $63 \%$ in controls to $93 \%$. VCL-1005 is moderately more effective, with $98 \%$ of cells now expressing HLA-B7; however, the more striking result is that these cells now express HLA-B7 at markedly higher levels as compared with cells transfected with VCL-1004. These data illustrate one of the values of co-transfection with both HLA class I chains, namely that $\beta 2 \mathrm{M}$ can not only increase the number of class I positive cells but also their level of MHC expression. This last point is particularly important as the density of HLA class I expression on melanoma cells has been shown to be directly proportional to the sensitivity of these cells to CTL lysis. ${ }^{16}$

Anti-tumor effect in a murine melanoma model

The ability of Allovectin to generate an anti-tumor effect was first explored in mouse tumor models, and in particular a commonly used model where a murine melanoma cell line (B16-F10) is implanted subcutaneously on the hind flank of C57BL/6 mice (the parental strain for this tumor) in order to generate a lesion that can then be directly injected with control or test articles. B16-F10 cells are an ideal system for testing Allovectin's proposed MOAs as these cells are poorly immunogenic due to, at least in part, a $\beta 2 \mathrm{M}$ deficiency. ${ }^{43}$ The cells do, however, express tumor antigens (apparently of retrovirus derivation), ${ }^{44}$ and if MHC class I expression can be restored, such as by IFN- $\gamma$ stimulation, ${ }^{43}$ the cells become susceptible to both CTL and non-MHC-restricted cell lysis.

An example of a proof-of-concept study conducted with Allovectin in this model is shown in Figure 1. An Allovectin dose of $100 \mu \mathrm{g}$ reduces the rate of tumor growth when delivered for 2 consecutive days, an effect only slightly increased when treatment duration is increased to 4 or 6 days. Studies such as this formed the basis for subsequent work in which other immunotherapies were combined with Allovectin in order to test for additive or synergistic responses.

\section{Allovectin and anti-CTLA-4 co-treatment}

One of the immunotherapeutics approved in 2011 for treatment of late-stage melanoma was the anti-CTLA-4 monoclonal antibody ipilimumab (Yervoy, Bristol-Myers Squibb, New York, NY, USA). When CTLA-4 expressed on T cells binds to CD80 or CD86 (for example, on antigen presenting cells), a T-cell inhibitory signal is generated. ${ }^{45} \mathrm{CD} 28$, also expressed by $\mathrm{T}$ cells, likewise binds to CD80 and CD86; however, this binding leads to the opposite effect, the generation of an activation or costimulatory signal. ${ }^{46-48}$

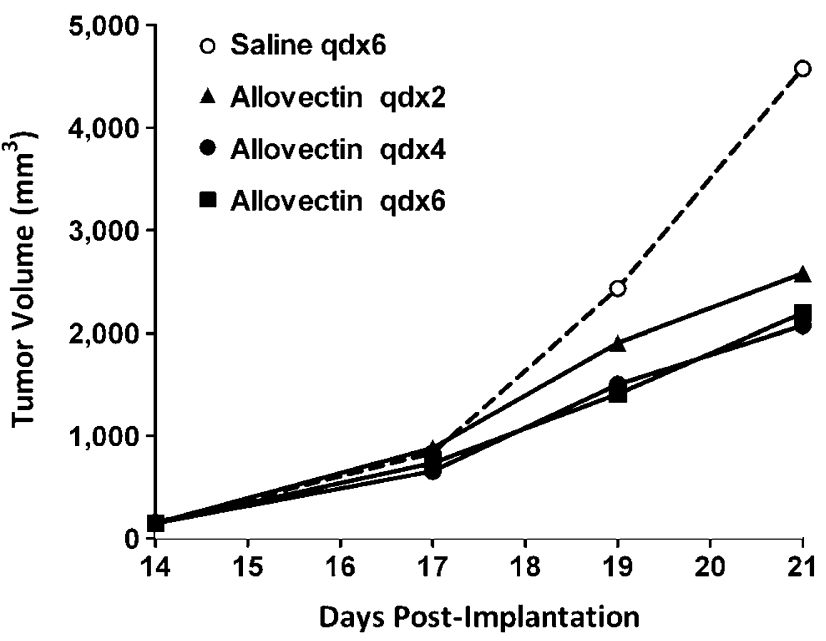

Figure 1. Allovectin anti-tumor efficacy in a murine melanoma model. C57BL/6 mice were implanted subcutaneously on the flank with B16-F10 murine melanoma cells. At 14 days when tumors were palpable $\left(50-300 \mathrm{~mm}^{3}\right)$, animals were randomized to receive either saline $(100 \mu \mathrm{l} \mathrm{qdx6)}$ or Allovectin $(100 \mu \mathrm{g}$ in $100 \mu \mathrm{l} \mathrm{qdx} 2,4$ or 6$)$. Tumor volume was then followed using caliper measurements and plotted vs days post-treatment.

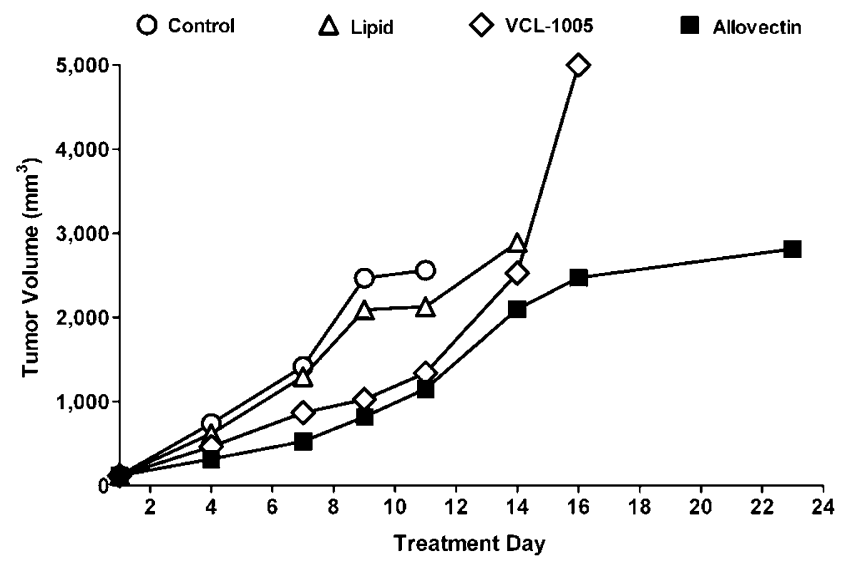

Figure 2. Combined Allovectin and anti-CTLA-4 antibody immunotherapy: Comparing between Allovectin, dimyristyloxypropyl-3dimethyl-hydroxyethyl ammonium/dioleoyl phosphatidylethanolamine (DMRIE/DOPE) and VCL-1005 treatments. C57BL/6 mice were implanted subcutaneously on the flank with B16-F10 cells. At 6 days when tumors were palpable (average of $120 \mathrm{~mm}^{3}$ ), animals were randomized to treatment groups (day 1). Groups included: Allovectin $(100 \mu \mathrm{g})$ plus $9 \mathrm{H} 10$ (hamster anti-murine-CTLA-4) or SHG-1 (hamster IgG control), VCL-1005 $(100 \mu \mathrm{g})$ plus $9 \mathrm{H} 10$ or SHG-1, DMRIE/DOPE ( $43 \mu \mathrm{g}$, the same lipid mass present in $100 \mu \mathrm{g}$ Allovectin) plus $9 \mathrm{H} 10$ or SHG-1, a no treatment control, and a $9 \mathrm{H} 10$ alone group. Allovectin, VCL-1005 and DMRIE/DOPE were delivered intratumorally as $50 \mu \mathrm{l}$ volumes on days $1-4 ; 9 \mathrm{H} 10$ and SHG-1 were delivered intraperitoneally as previously described. ${ }^{49}$ Tumor volumes were determined using calipers every 3 days; animals were euthanized if moribund or when tumors exceeded $1000 \mathrm{~mm}^{3}$. Data for the control antibody groups only are shown. $\bigcirc$ : no treatment control, $\Delta$ : DMRIE/DOPE-treated, $\diamond:$ VCL-1005-treated, $\mathbf{\square}$ : Allovectin-treated.

Blocking CD152 activity with antibodies such as ipilimumab, therefore, favors T-cell activation in two ways. First, it reduces the generation of an inhibitory signal. Second, by freeing CD80 and CD86 for binding to CD28, it enhances the opportunity for costimulation. 
The hamster anti-murine $\mathrm{CD} 152$ antibody $9 \mathrm{H} 10$ acts in a manner consistent with ipilimumab when examined in B16 tumor models. Delivered alone it has minimal effect on tumor growth, as few anti-tumor-reactive $T$ cells are available for activation in this model. However, if an anti-tumor response can be triggered using a different immunotherapeutic approach, $9 \mathrm{H} 10$ will enhance the activity of that response (for both CTL and NK cells). ${ }^{49}$ A combined treatment approach using both Allovectin and anti-CTLA-4 antibody should therefore yield similar results if the MOAs proposed for Allovectin are indeed correct, with Allovectin serving to generate an anti-tumor response that can then be enhanced by CTLA-4 blockade.

The results of such a study are shown in Figures 2-4. B16-F10 tumors established on the flanks of $\mathrm{C} 57 \mathrm{BL} / 6$ mice were directly injected with either Allovectin, VCL-1005 plasmid (without lipid formulation) or the lipid co-mixture DMRIE/DOPE (without pDNA), while at the same time animals received intraperitoneal injections of either $9 \mathrm{H} 10$ or a control antibody (an irrelevant hamster lgG). A control group received neither intratumoral nor intraperitoneal treatments. In the absence of anti-CTLA-4 treatment, Allovectin was the most effective treatment at reducing tumor volume relative to controls (Figure 2, $P<0.001$ ). VCL-1005 plasmid without lipid had a marked early anti-tumor effect; however, this was soon outpaced by renewed tumor growth, consistent with the need for a lipid formulation to maximize VCL-1005's anti-tumor activity. Finally, DMRIE/DOPE lipid on its own had relatively little effect, the expected result for a cationic lipid not complexed with pDNA. ${ }^{31,34-36}$

The same basic relationships between Allovectin and its individual components were also seen when animals were cotreated with anti-CTLA-4; however, the net contribution of systemic anti-CTLA-4 treatment varied depending on the treatment injected intratumorally. The ability of Allovectin to reduce tumor volume (Figure $3 b, P<0.001$ ) and improve survival (Figure $4 \mathrm{~b}, P<0.001$ ) relative to controls (Figures $3 \mathrm{a}$ and $4 \mathrm{a}$ ) was enhanced by the addition of anti-CTLA-4 treatment, resulting in a synergistic effect with the combined immunotherapies $(P<0.001)$ starting around treatment day 11 . This timing is consistent with a two-step model whereby Allovectin first induces a tumor-reactive T-cell repertoire followed by antiCTLA-4 activation of these cells. The similar but less pronounced ability of VCL-1005 plasmid to reduce tumor volume (Figure $3 c$, $P=0.014$ ) and increase survival (Figure $4 c, P=0.013$ ) relative to controls was also enhanced in a synergistic manner $(P<0.001)$ by anti-CTLA-4 antibody; this too was noticeable starting at about day 11, similar to the Allovectin plus $9 \mathrm{H} 10$ group's
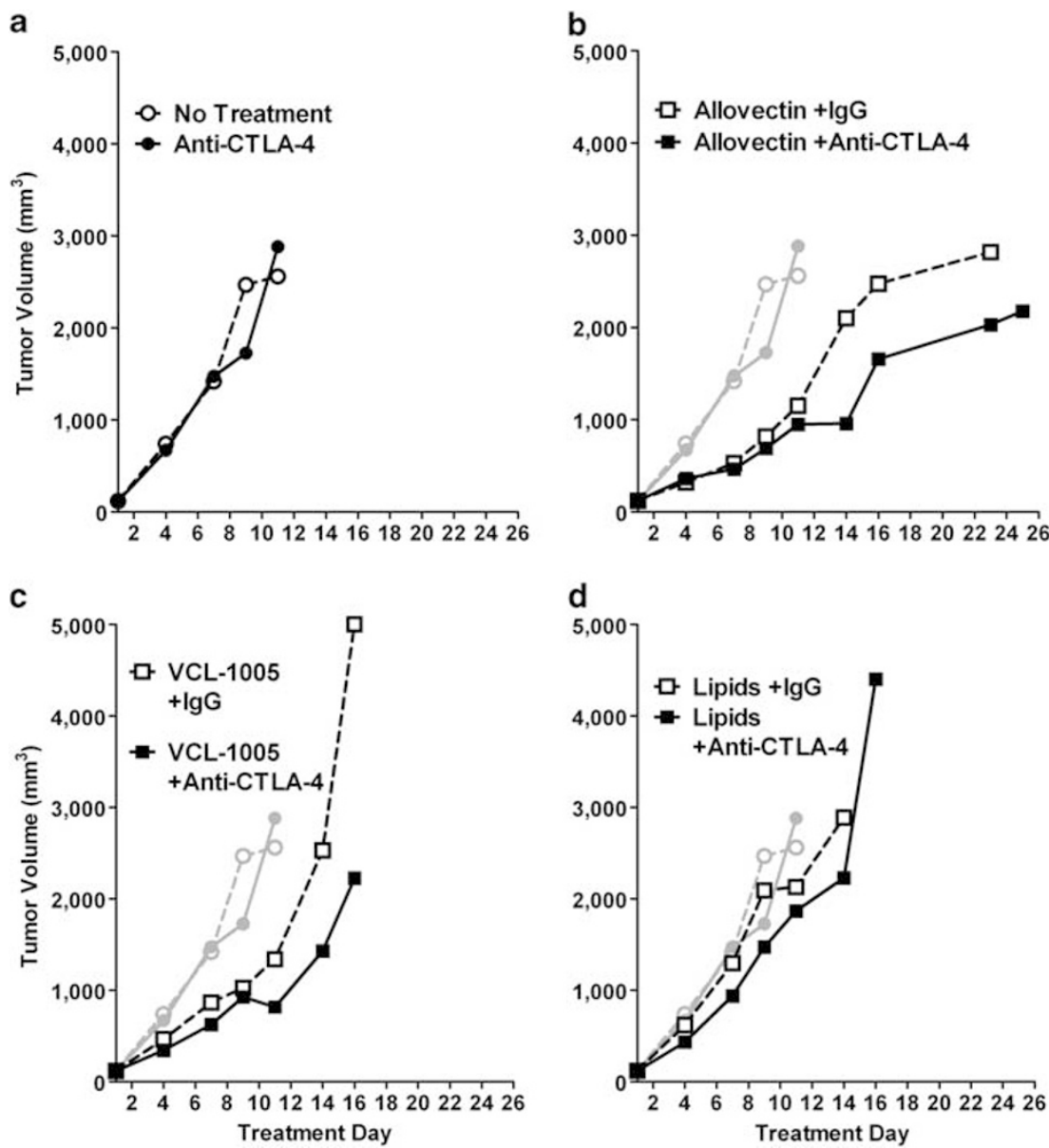

Figure 3. Combined Allovectin and anti-CTLA-4 antibody immunotherapy: Tumor volume. Data from the same study shown in Figure 2 are presented, but now both control and anti-CTLA-4-treated groups are shown. Tumor volume slopes were calculated for each animal and group means compared by one-way analysis of variance (ANOVA) analyses. Synergy was then estimated as $S=(\mu A-\mu B)-((\mu C-\mu B)+(\mu D-\mu B))$, where $A=$ combined treatment group, $B=$ control group, $C=9 \mathrm{H} 10$ alone group and $D=$ Allovectin, VCL-1005 or dimyristyloxypropyl-3dimethyl-hydroxyethyl ammonium/dioleoyl phosphatidylethanolamine (DMRIE/DOPE) alone group. (a) Control groups only; (b) control groups (gray) and Allovectin groups; (c) control groups (gray) and VCL-1005 groups; (d) control groups (gray) and DMRIE/DOPE groups. Groups receiving no antibody (a) or SHG-1 (b-d) are shown as open symbols connected with dotted lines, while groups receiving $9 \mathrm{H} 10$ are shown as solid symbols connected with solid lines. 
a

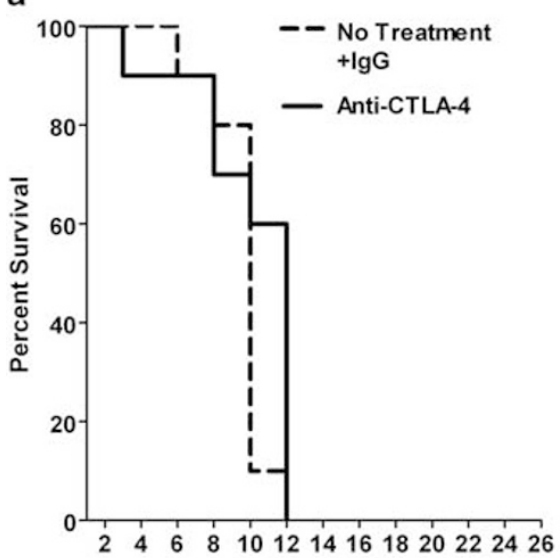

C

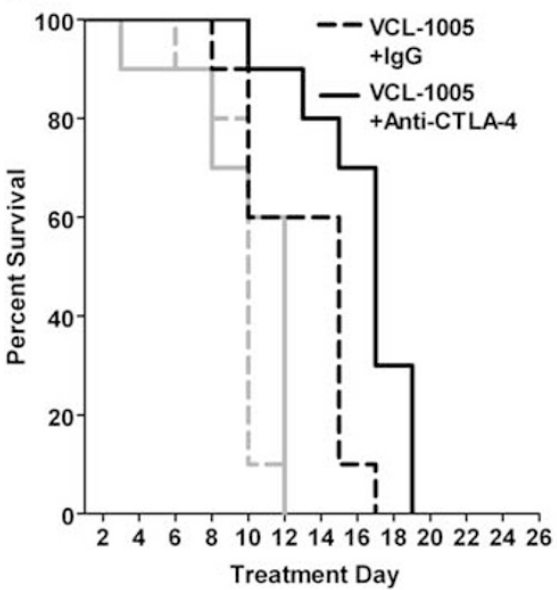

b

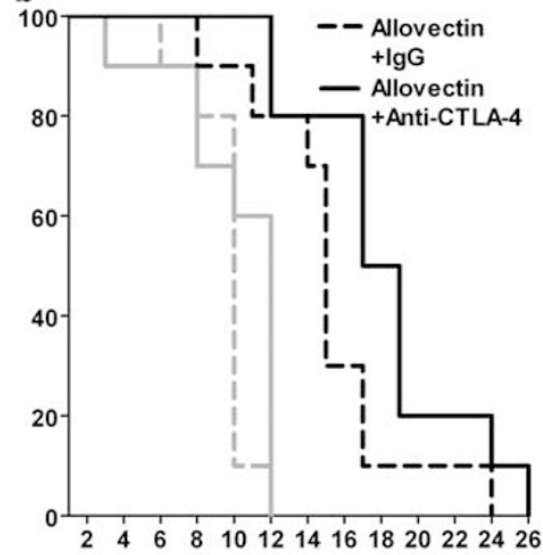

d

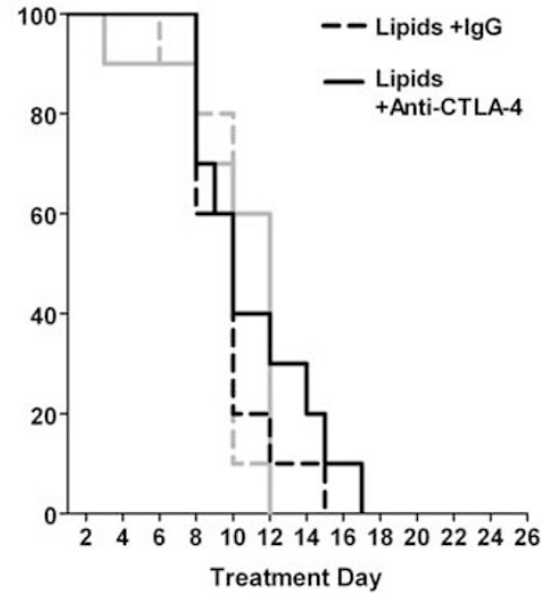

Figure 4. Combined Allovectin and anti-CTLA-4 antibody immunotherapy: Survival. Kaplan-Meier plots are presented for the study described in Figure 2. Data were compared using the logrank test. (a) control groups only; (b) control groups (gray) and Allovectin groups; (c) control groups (gray) and VCL-1005 groups; (d) control groups (gray) and dimyristyloxypropyl-3-dimethyl-hydroxyethyl ammonium/dioleoyl phosphatidylethanolamine (DMRIE/DOPE) groups. Groups receiving no antibody (a) or SHG-1 (b-d) are shown as dotted lines, while groups receiving $9 \mathrm{H} 10$ are shown as solid lines.

response. Finally, a combination treatment of DMRIE/DOPE and anti-CTLA-4 achieved a small but statistically significant tumor volume reduction by day 4 (Figure $3 d, P=0.025$ ); a trend towards improved survival was seen (Figure $4 d$ ) but did not reach the level of statistical significance. A modified two-step model can be proposed in this case, with DMRIE/ DOPE acting to induce an inflammatory response, which includes the recruitment of pre-existing immune cells, a response that on its own is insufficient for meaningful tumor killing but which can be boosted when combined with anti-CTLA-4. No real lag period is required before this anti-CTLA-4 effect can initiate, unlike with Allovectin and VCL-1005 where about 1-2 weeks is required during which a more optimally effective CTL response is generated. The lipid-recruited effector cells may be CTL, or more likely NK cells, as CTLA-4 blockade has been shown to stimulate NK cell-dependent killing in B16 models. $^{49}$

Data from this study are supportive of the multiple MOA model proposed for Allovectin, as the results observed are in agreement with many of the individual components of that model. In addition, the data agree with the developing concept that antiCTLA-4 therapies, while effective on their own, may be more effectively employed in combination with other treatments that induce immune system activation via distinct but complementary means. ${ }^{50}$ Blocking antibodies directed against programmed death 1 protein (PD-1, CD279) or its ligand PD-L1 (CD274), which have recently shown clinical promise as cancer immunotherapeutics, $^{51,52}$ are also likely to synergize with Allovectin, as their MOAs are similar to anti-CTLA-4 (that is, blockade of T-cell inhibitory signals).

Plasmid biodistribution in mice

In the ongoing phase 3 study, patients received 6 weekly injections of Allovectin ( $2 \mathrm{mg}$ delivered to a single lesion) followed by a 2-week rest period, then repeated this cycle after the 8-week period was complete. This regimen was designed in order to maximize the exposure of treated lesions to Allovectin. A study conducted in mice to follow plasmid persistence and biodistribution from injection sites supports this concept of using repeat injections in order to maintain local exposure, as it demonstrated that VCL-1005 steadily clears from injection sites without accumulating in distal tissues or organs.

CD-1 mice, evenly divided by sex, were injected subcutaneously over the left quadriceps on day 1 with either Allovectin $(10 \mu \mathrm{g}$ in a $25 \mu$ l volume) or vehicle. Tissue samples were taken at four time 
points spaced over a 2-month period, and VCL-1005 was quantified in tissue lysates using a quantitative PCR (qPCR) assay with a limit of detection (LOD) of 10 plasmid copy numbers (PCN) $\mu \mathrm{g}^{-1}$ DNA and a lower limit of quantification (LLOQ) of 50 PCN $\mu g^{-1}$ DNA.

Plasmid was undetectable in all samples taken from vehicletreated animals throughout the study, the expected result for this control group. For Allovectin-treated mice, VCL-1005 was consistently detectable at quantifiable levels in injection site skin and (to a lesser degree) in bone marrow; by contrast, plasmid levels were consistently $<$ LLOQ in blood, brain, gonads (ovaries and testes), heart, kidneys, liver, lungs, mesenteric lymph nodes, untreated skin and spleen (save for two untreated skin and one brain sample, presumably the result of cross-contamination). All injection site samples were $>$ LLOQ at the first three time points, with group means of $1.1 \times 10^{7}, 1.3 \times 10^{5}$ and $2.9 \times 10^{3} \mathrm{PCN} \mathrm{\mu g}^{-1}$ DNA at days 3, 15 and 29, respectively. At the final time point examined (day 61), 8 out of 10 injection site samples remained $>\mathrm{LLOQ}$, but at a relatively low group mean of $486 \mathrm{PCN} \mu \mathrm{g}^{-1} \mathrm{DNA}$; this represents a $>4$-log plasmid reduction at injection sites over the course of the study. As for bone marrow samples, 8 out of 10

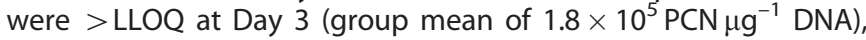
but at day 15 only 4 out of 10 were positive and the group mean had fallen to $555 \mathrm{PCN} \mathrm{\mu g}^{-1} \mathrm{DNA}$; at day 29 , all bone marrow samples scored below the assay LOD.

The presence of VCL-1005 plasmid at Allovectin injection sites is of course expected. The presence of plasmid in bone marrow samples is most likely a consequence of immune cells acquiring plasmid at the injection site and subsequently trafficking to the bone marrow as part of their normal recirculation pathways. ${ }^{53-55}$ Alternatively, free plasmid (rather than plasmid-containing cells) could have traveled to the bone marrow via the bloodstream; however, this scenario seems very unlikely as plasmid was undetectable in blood and highly vascularized organs (for example, liver, kidney, heart, lung).

In addition to the biodistribution study end points, a defined set of toxicology end points was also evaluated, allowing for the conclusion that Allovectin administration was well tolerated in this study. All animals survived to scheduled euthanasia, there were no treatment-related clinical observations or changes in body weights, and no test article-related observations were made at gross necropsy. The most obvious Allovectin-related finding was seen during microscopic examination of harvested tissues, namely a slightly increased incidence and/or severity of mixed cell infiltration at injection sites on day 3 . This increased infiltration, an expected finding based on Allovectin's proposed MOAs, resolved with time as it was not seen at subsequent time points.

\section{CLINICAL DATA SUPPORT}

The multiple MOAs proposed for Allovectin are supported not only by preclinical data but also by patient data gathered during the clinical development of this investigational immunotherapy. The most direct supporting evidence is that HLA-B7 expression can be detected in Allovectin-treated lesions biopsied from HLA-B7-negative patients, and that this is accompanied by an increase in tumorinfiltrating lymphocytes. ${ }^{56-58}$ These tumor-infiltrating lymphocytes contain HLA-B7-specific CTL, NK cells and lymphokine-activated killer (LAK) cells ${ }^{56-58}$ that when examined in vitro are capable of lysing both autologous melanoma cells and NK cell targets. ${ }^{56}$ In addition, the erythema and edema observed in injected lesions ${ }^{6}$ are consistent with the expected inflammatory response induced by cationic lipid/ pDNA complexes. The regression of distal non-injected lesions and as well as the development of vitiligo ${ }^{6,56}$ are indicative of the development of systemic responses, and responses in both HLAB7-positive and -negative patients ${ }^{6}$ are in agreement with the induction of anti-tumor (rather than simply allogeneic) responses. Finally, the increased CD80/86 expression observed on dendritic cells in and around Allovectin-treated lesions ${ }^{56}$ suggests that these costimulatory molecules contribute to Allovectin's immunotherapeutic effect, and so add credence to the hypothesis that combined Allovectin and anti-CTLA-4 treatment of advanced melanoma represents a promising avenue for exploration.

\section{SUMMARY}

Allovectin is proposed to act through multiple MOAs that draw from all its components: the plasmid, the lipid formulation and both pDNA-encoded transgenes. Together, they combine to increase immune recognition and destruction of cancer cells within the injected tumor lesion as well as at regional and distal metastases. Continued development of this drug product holds promise for a new immunotherapeutic option for advanced melanoma, one that functions through a set of mechanisms unique from, but complementary to, existing therapeutic approaches.

\section{CONFLICT OF INTEREST}

The authors are employees and stockholders of Vical Incorporated.

\section{ACKNOWLEDGEMENTS}

We thank all the past and present employees of Vical Incorporated, and in particular the Product Development, Pharmaceutical Sciences and Preclinical Safety and Efficacy groups, for their contributions to the development of Allovectin. Zelboraf is a registered trademark of Genentech Incorporated, and Yervoy is a registered trademark of Bristol-Myers Squibb Company.

\section{REFERENCES}

1 Cancer Facts and Figures 2012. American Cancer Society: Atlanta, 2012.

2 Chapman PB, Hauschild A, Robert C, Haanen JB, Ascierto P, Larkin J et al. Improved survival with vemurafenib in melanoma with BRAF V600E mutation. N Engl J Med 2011; 364: 2507-2516.

3 Hodi FS, O'Day SJ, McDermott DF, Weber RW, Sosman JA, Haanen JB et al. Improved survival with ipilimumab in patients with metastatic melanoma. $N$ Engl $J$ Med 2010; 363: 711-723.

4 Soares HP, Lutzky J. Velimogene aliplasmid. Expert Opin Biol Ther 2010; 10: 841-851.

5 Chowdhery R, Gonzalez R. Immunologic therapy targeting metastatic melanoma: allovectin-7. Immunotherapy 2011; 3: 17-21.

6 Bedikian AY, Richards J, Kharkevitch D, Atkins MB, Whitman E, Gonzalez R. A phase 2 study of high-dose Allovectin-7 in patients with advanced metastatic melanoma. Melanoma Res 2010; 20: 218-226.

7 Plautz GE, Yang ZY, Wu BY, Gao X, Huang L, Nabel GJ. Immunotherapy of malignancy by in vivo gene transfer into tumors. Proc Natl Acad Sci USA 1993; 90: 4645-4649.

8 Gonzalez-Galarza FF, Christmas S, Middleton D, Jones AR. Allele frequency net: a database and online repository for immune gene frequencies in worldwide populations. Nucleic Acids Res 2011; 39: D913-D919.

9 Peaper DR, Cresswell P. Regulation of MHC class I assembly and peptide binding. Annu Rev Cell Dev Biol 2008; 24: 343-368.

10 Williams DB, Barber BH, Flavell RA, Allen H. Role of beta 2-microglobulin in the intracellular transport and surface expression of murine class I histocompatibility molecules. J Immunol 1989; 142: 2796-2806.

11 Natali PG, Nicotra MR, Bigotti A, Venturo I, Marcenaro L, Giacomini P et al. Selective changes in expression of HLA class I polymorphic determinants in human solid tumors. Proc Natl Acad Sci USA 1989; 86: 6719-6723.

12 Natali PG, Viora M, Nicotra MR, Giacomini P, Bigotti A, Ferrone S. Antigenic heterogeneity of skin tumors of nonmelanocyte origin: analysis with monoclonal antibodies to tumor-associated antigens and to histocompatibility antigens. J Natl Cancer Inst 1983; 71: 439-447.

13 Ruiter DJ, Bergman W, Welvaart K, Scheffer E, van Vloten WA, Russo C et al. Immunohistochemical analysis of malignant melanomas and nevocellular nevi with monoclonal antibodies to distinct monomorphic determinants of HLA antigens. Cancer Res 1984; 44: 3930-3935.

14 Marincola FM, Shamamian P, Alexander RB, Gnarra JR, Turetskaya RL, Nedospasov SA et al. Loss of HLA haplotype and B locus down-regulation in melanoma cell lines. J Immunol 1994; 153: 1225-1237. 
15 Gasparollo A, Coral S, Ciullo M, Prisco A, Cattarossi I, Sigalotti L et al. Unbalanced expression of HLA-A and -B antigens: a specific feature of cutaneous melanoma and other non-hemopoietic malignancies reverted by IFN-gamma. Int J Cancer 2001; 91: 500-507.

16 Rivoltini L, Barracchini KC, Viggiano V, Kawakami Y, Smith A, Mixon A et al. Quantitative correlation between HLA class I allele expression and recognition of melanoma cells by antigen-specific cytotoxic T lymphocytes. Cancer Res 1995; 55: 3149-3157.

17 Al-Batran SE, Rafiyan MR, Atmaca A, Neumann A, Karbach J, Bender A et al. Intratumoral T-cell infiltrates and MHC class I expression in patients with stage IV melanoma. Cancer Res 2005; 65: 3937-3941.

18 Kageshita T, Hirai S, Ono T, Hicklin DJ, Ferrone S. Down-regulation of HLA class I antigen-processing molecules in malignant melanoma: association with disease progression. Am J Pathol 1999; 154: 745-754.

19 van Duinen SG, Ruiter DJ, Broecker EB, van der Velde EA, Sorg C, Welvaart K et al. Level of HLA antigens in locoregional metastases and clinical course of the disease in patients with melanoma. Cancer Res 1988; 48: 1019-1025.

20 D'Urso CM, Wang ZG, Cao Y, Tatake R, Zeff RA, Ferrone S. Lack of HLA class I antigen expression by cultured melanoma cells FO-1 due to a defect in $\mathrm{B}_{2} \mathrm{~m}$ gene expression. J Clin Invest 1991; 87: 284-292.

21 Wang Z, Cao Y, Albino AP, Zeff RA, Houghton A, Ferrone S. Lack of HLA class I antigen expression by melanoma cells SK-MEL-33 caused by a reading frameshift in $b_{2}$-microglobulin messenger RNA. J Clin Invest 1993; 91: 684-692.

22 Restifo NP, Marincola FM, Kawakami Y, Taubenberger J, Yannelli JR, Rosenberg SA. Loss of functional beta - $^{-m i c r o g l o b u l i n}$ in metastatic melanomas from five patients receiving immunotherapy. J Natl Cancer Inst 1996; 88: 100-108.

23 Hicklin DJ, Wang Z, Arienti F, Rivoltini L, Parmiani G, Ferrone S. b2-Microglobulin mutations, HLA class I antigen loss, and tumor progression in melanoma. J Clin Invest 1998; 101: 2720-2729.

24 Chang CC, Campoli M, Restifo NP, Wang X, Ferrone S. Immune selection of hotspot $b_{2}$-microglobulin gene mutations, HLA-A2 allospecificity loss, and antigenprocessing machinery component down-regulation in melanoma cells derived from recurrent metastases following immunotherapy. J Immunol 2005; 174: 1462-1471.

25 Hellstrom I, Hellstrom KE, Pierce GE, Yang JP. Cellular and humoral immunity to different types of human neoplasms. Nature 1968; 220: 1352-1354.

26 Lewis MG, Ikonopisov RL, Nairn RC, Phillips TM, Fairley GH, Bodenham DC et al. Tumour-specific antibodies in human malignant melanoma and their relationship to the extent of the disease. Br Med J 1969; 3: 547-552.

27 Park TS, Rosenberg SA, Morgan RA. Treating cancer with genetically engineered T cells. Trends Biotechnol 2011; 29: 550-557.

28 Mahato Rl, Rolland A, Tomlinson E. Cationic lipid-based gene delivery systems: pharmaceutical perspectives. Pharm Res 1997; 14: 853-859.

29 Nabel GJ, Nabel EG, Yang ZY, Fox BA, Plautz GE, Gao X et al. Direct gene transfer with DNA-liposome complexes in melanoma: expression, biologic activity, and lack of toxicity in humans. Proc Natl Acad Sci USA 1993; 90: 11307-11311.

30 San H, Yang ZY, Pompili VJ, Jaffe ML, Plautz GE, Xu L et al. Safety and short-term toxicity of a novel cationic lipid formulation for human gene therapy. Hum Gene Ther 1993; 4: 781-788.

31 Dow SW, Fradkin LG, Liggitt DH, Willson AP, Heath TD, Potter TA. Lipid-DNA complexes induce potent activation of innate immune responses and antitumor activity when administered intravenously. J Immunol 1999; 163: 1552-1561.

32 Yasuda K, Ogawa Y, Kishimoto M, Takagi T, Hashida M, Takakura Y. Plasmid DNA activates murine macrophages to induce inflammatory cytokines in a CpG motifindependent manner by complex formation with cationic liposomes. Biochem Biophys Res Commun 2002; 293: 344-348.

33 Cui Z, Han SJ, Vangasseri DP, Huang L. Immunostimulation mechanism of LPD nanoparticle as a vaccine carrier. Mol Pharm 2005; 2: 22-28.

34 U'Ren L, Kedl R, Dow S. Vaccination with liposome-DNA complexes elicits enhanced antitumor immunity. Cancer Gene Ther 2006; 13: 1033-1044.

35 Lanuti M, Rudginsky S, Force SD, Lambright ES, Siders WM, Chang MY et al. Cationic lipid:bacterial DNA complexes elicit adaptive cellular immunity in murine intraperitoneal tumor models. Cancer Res 2000; 60: 2955-2963.

36 Siders WM, Vergillis K, Johnson C, Scheule RK, Kaplan JM. Tumor treatment with complexes of cationic lipid and noncoding plasmid DNA results in the induction of cytotoxic T cells and systemic tumor elimination. Mol Ther 2002; 6: 519-527.

37 Sato $\mathrm{Y}$, Roman M, Tighe H, Lee D, Corr M, Nguyen MD et al. Immunostimulatory DNA sequences necessary for effective intradermal gene immunization. Science 1996; 273: 352-354.
38 Hemmi H, Takeuchi O, Kawai T, Kaisho T, Sato S, Sanjo H et al. A toll-like receptor recognizes bacterial DNA. Nature 2000; 408: 740-745.

39 Krieg AM. CpG motifs in bacterial DNA and their immune effects. Annu Rev Immunol 2002; 20: 709-760.

40 Yasuda K, Ogawa Y, Yamane I, Nishikawa M, Takakura Y. Macrophage activation by a DNA/cationic liposome complex requires endosomal acidification and TLR9dependent and -independent pathways. J Leukoc Biol 2005; 77: 71-79.

41 Fox BA, Drury M, Hu HM, Cao Z, Huntzicker EG, Qie W et al. Lipofection indirectly increases expression of endogenous major histocompatibility complex class I molecules on tumor cells. Cancer Gene Ther 1998; 5: 307-312.

42 Hicklin DJ, Dellaratta DV, Kishore R, Liang B, Kageshita T, Ferrone S. b b $_{2}$-microglobulin gene mutations in human melanoma cells: molecular characterization and implications for immune surveillance. Melanoma Res 1997; 7(Suppl 2): S67-S74.

43 Seliger B, Wollscheid U, Momburg F, Blankenstein T, Huber C. Characterization of the major histocompatibility complex class I deficiencies in B16 melanoma cells. Cancer Res 2001; 61: 1095-1099.

44 Leong SP, Muller J, Yetter RA, Gorelik E, Takami T, Hearing VJ. Expression and modulation of a retrovirus-associated antigen by murine melanoma cells. Cancer Res 1988; 48: 4954-4958.

45 Krummel MF, Allison JP. CD28 and CTLA-4 have opposing effects on the response of T cells to stimulation. J Exp Med 1995; 182: 459-465.

46 Lesslauer W, Koning F, Ottenhoff T, Giphart M, Goulmy E, van Rood JJ. T90/44 (9.3 antigen). A cell surface molecule with a function in human $T$ cell activation. Eur $J$ Immunol 1986; 16: 1289-1296.

47 Linsley PS, Clark EA, Ledbetter JA. T-cell antigen CD28 mediates adhesion with B cells by interacting with activation antigen B7/BB-1. Proc Natl Acad Sci USA 1990; 87: 5031-5035.

48 Azuma M, Ito D, Yagita H, Okumura K, Phillips JH, Lanier LL et al. B70 antigen is a second ligand for CTLA-4 and CD28. Nature 1993; 366: 76-79.

49 van Elsas A, Hurwitz AA, Allison JP. Combination immunotherapy of B16 melanoma using anti-cytotoxic T lymphocyte-associated antigen 4 (CTLA-4) and granulocyte/macrophage colony-stimulating factor (GM-CSF)-producing vaccines induces rejection of subcutaneous and metastatic tumors accompanied by autoimmune depigmentation. J Exp Med 1999; 190: 355-366.

50 Postow MA, Callahan MK, Barker CA, Yamada Y, Yuan J, Kitano S et al. Immunologic correlates of the abscopal effect in a patient with melanoma. $N$ Engl J Med 2012; 366: 925-931.

51 Topalian SL, Hodi FS, Brahmer JR, Gettinger SN, Smith DC, McDermott DF et al. Safety, activity, and immune correlates of anti-PD-1 antibody in cancer. N Engl J Med 2012; 366: 2443-2454.

52 Brahmer JR, Tykodi SS, Chow LQ, Hwu WJ, Topalian SL, Hwu P et al. Safety and activity of anti-PD-L1 antibody in patients with advanced cancer. $N$ Engl J Med 2012; 366: 2455-2465.

53 Di Rosa F, Santoni A. Memory T-cell competition for bone marrow seeding. Immunology 2003; 108: 296-304.

54 Parretta E, Cassese G, Barba P, Santoni A, Guardiola J, Di Rosa F. CD8 cell division maintaining cytotoxic memory occurs predominantly in the bone marrow. $J$ Immunol 2005; 174: 7654-7664.

55 Massberg S, Schaerli P, Knezevic-Maramica I, Kollnberger M, Tubo N, Moseman EA et al. Immunosurveillance by hematopoietic progenitor cells trafficking through blood, lymph, and peripheral tissues. Cell 2007; 131: 994-1008.

56 Nabel GJ, Gordon D, Bishop DK, Nickoloff BJ, Yang ZY, Aruga A et al. Immune response in human melanoma after transfer of an allogeneic class I major histocompatibility complex gene with DNA-liposome complexes. Proc Natl Acad Sci USA 1996; 93: 15388-15393.

57 Rubin J, Galanis E, Pitot HC, Richardson RL, Burch PA, Charboneau JW et al. Phase I study of immunotherapy of hepatic metastases of colorectal carcinoma by direct gene transfer of an allogeneic histocompatibility antigen, HLA-B7. Gene Ther 1997; 4: $419-425$.

58 Stopeck AT, Hersh EM, Akporiaye ET, Harris DT, Grogan T, Unger E et al. Phase I study of direct gene transfer of an allogeneic histocompatibility antigen, HLA-B7, in patients with metastatic melanoma. J Clin Oncol 1997; 15: 341-349.

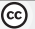
SOMERIGHIS HESERVED NonCommercial-No Derivative Works 3.0 Unported License. To view a copy of this license, visit http://creativecommons.org/licenses/by-nc-nd/3.0/ 